\title{
Axes of entanglement in the New Georgia group, Solomon Islands
}

\author{
Tim Thomas
}

Regional exchange networks of great variety and complexity are among the most studied phenomena in archaeological and ethnographic accounts of Island Melanesia. Malinowski's (1922) pioneering ethnography of the kula system of southern Papua New Guinea produced an enduring image of exchange as foundational to Melanesian social life, and subsequent ethnographic efforts dedicated to elucidating the role of exchange in political structures, gender relations, ritual and symbolism (Leach and Leach 1983; Strathern 1988), have made lasting contributions to social theory. Archaeologists, for their part, have focused on identifying the range and pattern of exchange networks - from the expansive material transfers of the Lapita cultural complex (Kirch 1988; Summerhayes 2000) to the development of smaller but more intensive networks of later periods (Allen 1984).

However, despite a common interest in these networks, archaeological and ethnographic accounts of the region remain distinct both in terms of approach and in what they take exchange phenomena to mean. Archaeological accounts tend to be resolutely materialist, tracking distributions of objects as a signal of interaction and mobility, for reasons that are, at root, culture historical. Because the archaeological data of exchange are artefact finds, archaeologists tend to explain exchange via object properties, as the redistribution of valued material. In contrast, ethnographic work in the region is comparatively idealist, seeing exchange as the definition and manipulation of social relations via the symbolism of exchange media. Where archaeologists find reasons for exchange in the properties of objects, ethnographers find reasons in the meaning of relations.

This contrast of 'objects' versus 'relations' focused approaches to exchange maps straightforwardly onto a theoretical distinction between commodity and gift economies. In Marx's (1976:164-165) classic definition of commodity fetishism, value created during relations of production comes to be seen as a socio-natural property of the thing itself. In such systems, value is established by comparing objects, and ultimately even relations between people are objectified and patterned after relations between objects (Lukács 1971). Conversely, gift economies create lasting chains of obligations between persons, such that exchange objects are valued only insofar as they make manifest or embody relations. If people and things assume the social form of objects in a commodity economy, then in a gift economy they assume the social form of persons (Gregory 1982:41; Mauss 1990). Accordingly, when archaeologists and ethnographers explain exchange in different ways they also imply different kinds of economy.

Understanding the source of this difference is helped by considering exceptions. These tend to occur only when data and interest overlap-archaeologists working on museum collections and the recent past, for example, have sometimes taken relational approaches (Flexner 2016; 
Gosden 2004; McNiven 2013; Torrence and Clarke 2013). Generally, the more our data consist solely of objects (i.e. the longer the time before present), the more likely we are to rely on materialist explanations. One reason for this is that Western ontologies consider meaningful relations to be an immaterial product of human cognition - the work of living minds - and consequently inaccessible when the people are gone. Ethnographic idealism is the flip side of the same coin: when the people are still present, artefacts are considered superfluous to the discovery of meaning, rendered 'merely illustrations' (Strathern 1990:171). This suggests that our apparently data-driven division in explanatory frames is actually the product of an underlying limit to the common way we think about subjects and objects.

The way we explain exchange is a token of this conceptual limit, and this has been an important focus in attempts to transcend it. The distinction between gift and commodity economies, for example, is emblematic of deeper conceptual differences in the way subjects, objects and relations are conceived. Strathern (1988) points out that whereas Western commodity systems are reliant upon a conception of individuals and objects as autonomous categories ontologically prior to, and conceptually separate from, their relations, Melanesian gift economies consider relations to be ontologically prior to any objects or persons that might emerge from them. People (and things) in the latter view are consequently not individuals at all, but rather composite sites of relations, and are thus 'dividual'. Broadening the implications of gift economies in this way, Strathern develops a Melanesian model of sociality in which the primary concern of social life is not how to create lasting relations between persons and other entities, but rather how to create distinct persons and things out of pre-existing relations. In this sense the model can be taken as comparable to other recent critiques of modernist assumptions and Enlightenment-era dualisms (e.g. subject-object, mind-body, culture-nature). Latour's (1993) actor-network theory (ANT) is a well-known example, arguing for a symmetrical anthropology in which people and things are linked as equivalent 'actants' in network arrangements, and that it is this relationality that produces the effects, discoveries, objects and distinctions of our cultural concern.

In archaeology, Ian Hodder's recent development of entanglement theory (2012) is inspired by these insights and deploys them to interrogate long-term patterns of human-thing relations via archaeological data. Hodder argues that humans and things co-constitute each other in increasingly complex networks of relations; however, his approach is an attempt to bridge the gap between purely relational and materialist, object-oriented models. Finding that Latour and Strathern overemphasise relations at the expense of an understanding of how material entities produce real effects and constraints that last beyond their current connections, Hodder builds hierarchical or asymmetrical relationships into his model (Hodder 2014:22-25). His key focus is on 'entrapment', a process by which people and things become dependent on each other in ever-increasing entanglements that have both positive and negative consequences. Disentanglement, or the separation of people and things from their constituting relations, is thought to be temporary and ultimately impossible beyond local occurrences.

Hodder's approach then, raises the prospect of integrating archaeological and ethnographic insights in Melanesia, of balancing the material and relational. But in doing so it comes with some problems. Like other accounts developed in reaction to Western models of object autonomy, Hodder spends most of his time mapping out the complex networks of relationships underlying forms we take for granted. Latour does the same, and has recently satirised his own tendency to repeatedly focus on the 'surprise' of finding that ANT analysis reveals that the objects and domains we take to be distinct are 'actually' composed of heterogeneous networks (Latour 2013:35). Surely if reality is relational we should be more surprised that objects are claimed to exist and endure? However satisfying it is to undermine taken-for-granted objects by showing that they are relationally constituted, it still leaves the challenge of defining how they are made to appear autonomous at all. 
Early ANT provided a way of conceptualising this as 'punctualisation'-a simplification or encapsulation of network parts to make actants that exist in relation to others, and thus form larger-scale networks (Law 1992:384-385). And despite being usually taken as purely relational, Strathern's (1988) account of Melanesian sociality makes a similar argument by showing, for example, how collective events create images of group unity by encompassing their many internal relations, or how a gift exchange creates an oppositional pairing of persons occluding the many relations of production underlying the gift. In later work Strathern (1996) refers to these objectification processes as 'cutting the network'-offering the parallel example of patents, which create property objects by encompassing and eclipsing the network of relations that led to the discovery (prior studies, chains of research results etc.). The wider point is that social life involves an endless movement between relational entanglement and objectification. Far from disentanglement being of minor temporary importance, it is often the very focus of relations.

In the following case study I attempt to show how the circulation and use of a single class of artefacts can act as the fulcrum point for processes of both entanglement and network cuttingthat is, the production of relations and the production of objects with definite properties. Furthermore, these processes can be seen to operate at various scales relevant to the scope of both ethnographic and archaeological enquiry.

\section{Entanglement in New Georgia}

Archaeological research in the New Georgia group of the Solomon Islands has identified a late period cultural sequence documenting the establishment of a coastal polity in the Roviana region after 400 BP (Sheppard and Walter 2006), with parallel changes on other islands throughout the group slightly later (Thomas 2009, 2014). This sequence is marked particularly by changes in the occurrence, layout and density of settlement sites and ritual monuments. Prior to $400 \mathrm{BP}$, dispersed monumental shrines and settlements occurred on isolated ridgelines in the interior of islands, but these were subsequently abandoned in favour of sprawling composite villages on the coast, featuring numerous shrines of diverse function in close association with house platforms, wharves and fortified areas (Sheppard et al. 2000; Walter and Sheppard 2000). By the mid-1800s these communities had come into sustained contact with European whalers, traders and naval ships, and lasting historical records and early ethnographies attest to expansive regional relationships spanning most of the western Solomons (Bennett 1987; Hocart 1922; McKinnon 1975).

These changes reflect a late period shift in political and social focus towards seaborne trade networks and expanding cycles of headhunting raids-success in these becoming increasingly seen as primary indices of chiefly and tribal efficacy. Tribal groupings formed around lineages of successful warrior chiefs (bangara) whose ability to manipulate regional alliance and trade relationships helped fund collective raids against neighbouring islands. Successful headhunting was taken to be ancestral sanction made manifest-a state of being mana, or efficacious, promising that ancestral spirits would join descendants in all endeavours and the tribe would prosper. Note that, in the languages of New Georgia, mana is not a substantive noun indicating some spiritual substance, but rather refers to a relational state of spiritual cooperation. Shrines, housing ancestral skulls and shell valuables, were the focal point of ancestral propitiation and maintenance of that cooperation. By controlling access to shrines, leaders controlled the ritual life of the community and, by extension, other realms of ritually dependent practice (Sheppard and Walter 2006; Thomas 2014). 
McKinnon (1975) and Zelenietz (1979) both argue that new economic opportunities offered by recently arrived European traders fuelled an expansion of headhunting during the 19th century. McKinnon focuses on the introduction of iron tools, particularly the 'tomahawk' or axe head, which became a staple item of early trade and a key weapon used in headhunting raids. Iron axes are common finds on shrines in New Georgia, indicating their complete integration into local practice (Thomas et al. 2001:553; Walter et al. 2004). McKinnon (1975) argues that they increased productivity, affording more time away from primary food production and, as weapons, were superior to indigenous equivalents. Leaders in key locations courted European favour, and monopolised access to trade goods in order to achieve military dominance over lesserequipped rivals. Having achieved dominance, well-connected leaders were able to supply more of the resources (hawksbill turtle shell, or 'tortoiseshell') that Europeans wanted, and could parlay this against acquiring more European things and more military power. In other words, exogenous technology disrupted political equilibrium by freeing up time to spend on more effective violence and domination, leading to a society spiralling out of control—until pacification by British colonial powers in the 1890s.

McKinnon's (1975) account is an early attempt to approach the social effects of people-thing entanglement, and like Hodder (2012) depicts this as a process of entrapment leading to everincreasing cycles of dependence. But it is also clear in subsequent research that McKinnon gets many of the ethnographic details wrong (Aswani 2000; Dureau 2000). The timeline, too, is challenged by the archaeological demonstration of much earlier indicators of intensive headhunting (Sheppard et al. 2000), although raiding certainly expanded in range in the latter half of the 19th century. Moreover, such accounts reflect a kind of instrumental 'substantivism' (Feenberg 1991:7-8) in which taken-for-granted properties of iron have explanatory agency. Although it is obvious that the advent of European trade introduced new things and networks of trade, and thus new social possibilities for action, it is not clear that it was only the properties of objects that motivated Solomon Islanders' negotiations of these changes.

It is worth reflecting on the fact that shrines are the primary depositional context of iron axes in New Georgia. This is not, in itself, an indication that axes made of iron in particular were special items of high value or mystery. There is no detectable pattern of association between iron axes and types of shrine for example, and stone axes are found deposited on older shrines in exactly the same way, indicating a seamless integration of materials (Thomas 2004:328-335). Axes were interred along with the crania and other belongings of the dead during rituals of enshrinement (Walter et al. 2004). As such, they occur alongside local products (shell valuables, tools) as well as other materials of European origin (willow pattern ceramics and stoneware, parts of firearms, metal cookware, pipe stems, hoop iron). This conforms to the indigenous appropriation' of European things described by Thomas (1991) — new forms were subsumed into existing categories. Placed on shrines at the end-point of a transcultural biography, such artefacts had become fully absorbed into the habitus of life in 19th-century New Georgia. They belonged on shrines as much as the bones of their local owners, because, by the late 1800 s, a person was a product of relations that extended beyond New Georgia.

In the following I take another look at the changing political economy of axes in New Georgia, starting with an account of the status of axes in local conception and practice. 


\section{Clubs (axes) appear}

According to contemporary observations, iron axes were ubiquitous by the 1860 s (Shineberg 1971). Hocart, on Simbo in 1908, describes them as follows:

The so-called tomahawk is by the natives termed manja, like the aboriginal club it has displaced. It is made with Harrison's No. 2 iron blade set upon a handle $90 \mathrm{~cm}$. long, with a section like that of a convex lens. It is broadest below the axe head, where it is curved with the convex side towards the blade. The extremity is pointed to be stuck in the earth, for the owner will never lay it down flat while he is squatting, but always keeps it planted head up, and when one of us used to lay his tomahawk down it was always set upright again. This is doubtless founded in caution, for it is sooner snatched into the right position; besides that, it is easier to keep in sight. Rapidity also accounts for keeping the edge of the blade upward when shouldering it. (Hocart 1931:301)

These conventions of orientation might also be explained by the social status of axes, as being more than inanimate objects. Axe handles were heavily ornamented with carvings and shell inlay, using motifs reserved for the embodiment of spiritual potency. As with other inlaid artefacts, such as war canoes, these motifs are abstract depictions of spirits occurring in long chains or lineages (see Thomas 2013). Handles were sometimes carved with predatory figures, so that the blade emerges from the mouth of a crocodile and/or frigate bird (Figure 7.1). Items decorated in this way appeared as manifestations of a violent ancestral efficacyan immanent spirit in particular form. Axes thus had attributes of personhood, and accordingly were treated as if they had a proper orientation, an appropriate 'posture'.

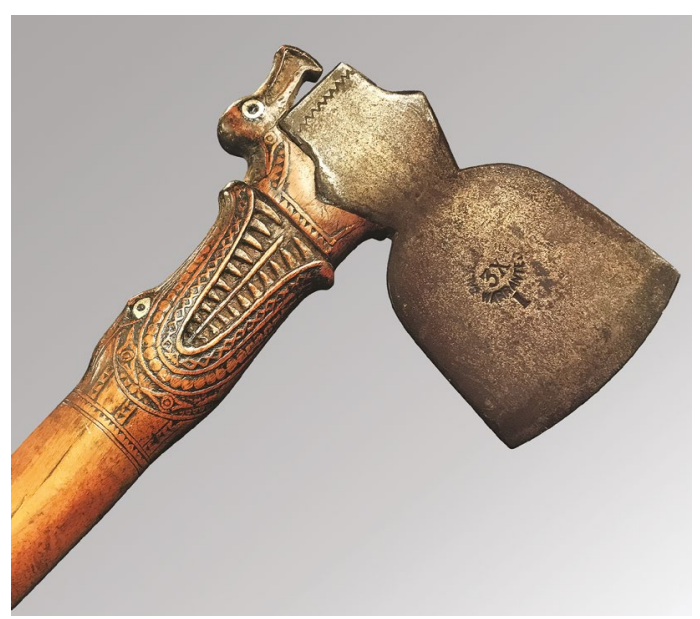

Figure 7.1. Hafted trade axe, 19th century, Roviana Lagoon.

Source: Photo by Hughes Dubois (Waite and Conru 2008:Figure 78), used with permission.

This can be clearly seen in the ceremonial treatment of axes during preparatory ceremonies of headhunting and in those conducted after successful return. Hocart (1931) recorded these ceremonies at chiefly shrines called inatungu. Prior to a raid, warriors would gather at the shrine and make offerings of shell valuables and burnt food to the spirits in a ceremony known as votu manja 'clubs/axes appear' or 'bring out the clubs/axes', chanting: 'This is the club, thou the inatunu. Grant me an enemy to slay, and let me club ... be efficacious you spirits. Grant a victim' (Hocart 1931:308). These ceremonies effectively called forth the efficacy of those dead warrior chiefs who had achieved success in their own lifetimes, enlisting this in contemporary practice. The weapons embodied the presence of these potent spirits on a raid.

In the event of a warrior successfully capturing an enemy head, the entire community would gather to make parcelled offerings of shell rings, puddings and pigs, lacing these along the handle of the weapon while the person who wielded it sat out of sight, as described here again by Hocart:

Minju [the successful warrior] set up his club [tomahawk] and retired to the house at the back. One man blew the conch. When it sounded the women lined up, Mali, the wife of Kundaite [the chief], first. They squatted down till the conch had blown four times. When it ceased, a man went up first and laid before the tomahawk a basket of food, including the head and shoulders of a pig. The women followed. Mali took out the tomahawk, laid a ring down, and stuck the tomahawk through it; the other women laid down each a pudding crowned with a ring. Then men followed with the same. When the list was exhausted Minju and Mali came up. Mali pulled out the 
tomahawk, but so that her ring remained hanging upon it. She then passed a stem of piro through the ring, applying it to the handle of the tomahawk. She took the rings from each pudding and slipped them up the tomahawk and piro. Seizing the ends of the piro in one hand, she then drew out the tomahawk, tied up the ends of the piro and carried it off. (Hocart 1931:316)

The first ring laid down and threaded along the handle of the axe by Mali was the singe inatungu or sacred ring of the shrine, and it was used to gather up those rings offered on top of puddings by the community. All except the sacred ring were given to the successful warrior as compensation for securing a victim. However, the warrior later gave the rings to the attendant of the inatungu shrine who had conducted the initial 'clubs appear' ceremony, because they were ultimately owed to the spirits of that shrine in recognition of the true source of success: the ancestors (Hocart 1931:316; Thomas 2004:272-274).

The performance of the ceremony of return then, acknowledges the relational nature of agency in New Georgia - a warrior was only successful as such due to his axe, which was only efficacious because of the ancestral spirits it embodies, whose own success when alive also depended on similar relations with previous ancestral spirits, and so on. Importantly however, at each stage in this chain encompassment occurs. When threaded with the singe inatungu ring and community offerings, the axe presented a composite image of successful action arising out of collaboration between a warrior and propitiated spirits - as the focal point of the ceremony it was an agent, an object eclipsing its relations. When the warrior received the rings he similarly eclipsed the axe and the spirits. And when the warrior gave the rings back to the inatungu shrine, the chiefly lineage, and tribe itself, encompassed his success.

The latter encompassment is made possible by the fact that the inatungu shrine was the seat of local tribal identity. In Roviana inatungu is the nominalised form of atungu, the respectful term for the 'sitting' or 'high chief', and in nearby Marovo the inatungu is the apical founding spirit of the chiefly lineage, and thus the source of all tribal agency (Hviding 1996:125). Indeed, it was chiefs who organised headhunting raids and so initiated the 'clubs appear' ceremony. The community was totally implicated in these projects because it was only through lateral patron-client relations with tribal members that chiefs could act in the manner befitting a leader. The community was involved from the start in preparing feasts and gathering resources for a raid.

Axes used in headhunting were clearly entangled with the definition of persons and internal relations in the performance of tribal agency. In managing raids, chiefs also used axes to manage the limits of tribal boundaries. Headhunting itself encompassed internal relations in opposition to a realm of asocial violence-it cut a much wider potential network. In Roviana oral histories archetypal episodes of violence conducted by chiefs are those that result in the fissioning of tribes. Tae-Bangara (c. 1750-1780) for example, is remembered as a ruthless and eager warrior, who, through success in warfare, established the zenith of Roviana political dominance. But, his ruthlessness extended to killing rival kinsmen, and he was eventually murdered by the warriors of his brother Odikana who then left to form the Saikile District. The sons of Tae-Bangara (Qutu, Gove, Raro) again fought amongst themselves and created further splits in the Roviana polity, with Raro and Gove establishing the Munda District (Aswani 2000:50-51). Rather than integrating competing tribes, surrounding islands like Tetepare and southern Rendova were depopulated by raiding. Chiefs of the late 19th century modelled themselves on the exploits of these ancestors-Nona of Kalikoqu, Lepe of Kindu, and most famously, Ingava of Sisiata, are renowned as rulers who demonstrated the supremacy of Roviana tribes by conducting increasingly large-scale and frequent raids on Choiseul and Santa Isabel (see also Chapter 9 this volume). Somerville famously recorded (or exaggerated) that on one occasion Ingava:

went away on a headhunting expedition to Ysabel Island ... He took twenty tomako (war canoes) containing about five hundred men, and two good-sized English built boats, containing between three and four hundred rifles, and nine thousand rounds of ammunition. (Somerville 1897:399) 
It was raids like these, and their impingement on the safety and dealings of European residents, that ultimately drew the British Government to establish a protectorate and enforce peace.

This tension between raiding and its internal versus external consequences reflects the dual role of chiefs as managers of war and managers of peace and alliance. Ingava, for example, is remembered as 'a very good bangara, for he never fought a Munda man' (Hocart n.d.[a]:20), and seems to have occasionally brokered peace between warring factions (Hocart 1931:305). Such chiefs spanned an oppositional crux in Roviana sociality - they managed boundaries by defining relations in terms of enemies and friends, outsiders and insiders, foreigners and kin. On the one hand a chief's role as the entrepreneurial head of a cognatic descent group tended to accumulate followers, alliances and relationships, but on the other, leadership in headhunting established difference. Tae-Bangara and his sons are remembered as 'great' because they successfully differentiated currently recognised tribes through violent endeavour - they managed descent group integrity by making enemies of kin who threatened to diffuse that integrity. If cognatic kinship, exogamous marriage and ceremonial life could result in potentially boundless relations, then warfare was a particularly effective way of creating difference and managing those boundaries (Scheffler 1965).

So, if axes were personified, then the effect of their use in headhunting was to objectify persons. Taking heads was an extreme form of alienation in that it denied people their personhood, turning them into objects: trophy heads. In killing enemies, warriors destroyed the efficacy of another group: by defeating the ancestral potency of their rivals; by abducting heads so that they could not be enshrined; and by creating malevolent spirits filled with rage at their improper death (Dureau 2000). Defeat in these terms was tantamount to social erasure-objectifying enemies was not so much a matter of encapsulating a set of relations, but rather denying these existed at all. Indeed, even captives were 'really supposed to be dead' (Hocart 1931:306) because they were alienated from their relations and origins. When raids returned with captives, ceremonies were staged to explicitly erase their prior social connections to people and place-the inatungu spirit of other places was ritually removed and replaced with the inatungu of the new locale (Hocart 1931:313) in order to facilitate the refiguring of the captive as kin (McDougall 2000:104). Heads, in contrast, simply became object indices of successful raiding. The hair and ears of the victim were burned to feed the inatungu (Hocart 1931:314) rendering the head void of any personal content. Hung in the rafters of the paele men's house, heads were considered pinerathings taken by force, without compensation. Consequently, the effect of headhunting was to offset or enframe sociality - it did not present one tribe as the most potent amongst many other (enemy) tribes; it claimed potency, personhood and relational sociality as the sole province of the victors and their allies.

According to my argument then, axes were entangled in crucial practices facilitating the definition of persons and objects out of fields of relations. Axes made agency visible in certain ways by helping eclipse or cut these relations at different scales. But axes were also relationally produced, and not only as vehicles of spiritual potency — they also had to be acquired through trade.

\section{Acquiring axes}

As noted in Hocart's account, axes on Simbo were subsumed under the category of 'club' or manja. Prior to iron axes, manja were paddle-shaped and made of heavy wood (Hocart 1931:301). In Roviana however, the wooden club was known as vedara, whilst axes were generically called maho. The long-handled stone-headed battle axe was karamaho. Very few of these stone axes have appeared in publications, but the most common was a 'waisted blade' axe with a lenticular crosssection, made from a large flake of volcanic rock. Specimens of this type are present in museum collections (some taken from shrines) and are known from sites like Panaivili (Reeve 1989:57) 
and elsewhere in Roviana (Felgate 2003:410), Rendova and Tetepare (Thomas 2009). Specimens of a second variety - a polished axe with an oval cross-section, made from a very fine-grained light-grey or greenish rock-have been recorded on Nusa Roviana (Nagaoka 2011:129; Thomas 2004:296) and at Panaivili (Felgate 2003:409). Miller (1979:152-155) has summarised the axe and adze collections in the Solomon Islands National Museum, finding that the majority of the New Georgian specimens are of the lenticular cross-section form (64 per cent vs 27 per cent oval cross-section), while those from Choiseul and Isabel are mainly the oval variety (65 per cent). Specimens of large flanged axes with side lugs and bosses have been found on Simbo but conform to the style of 'ceremonial' axes from the Bougainville-Choiseul area (Specht 1979).

Although no geological sourcing studies have been carried out beyond description of hand specimens (Felgate 2003:407-411), an argument can be made that most of the stone axes found in the Roviana region, and probably Simbo too, were specialist products acquired through trade partnerships. The oval cross-section axes described above were not only more common in Isabel and Choiseul but there are no known local sources of the fine-grained grey stone (possibly metamorphosed sedimentary rock, found in Isabel, Choiseul and Guadalcanal (Coulson 1985:639-641)). The lenticular cross-section axes may have been manufactured in the New Georgia archipelago given that they are made from coarse volcanics and are the most common variety. However, such axes were probably a specialist product made by people with good access to suitable stone. In Roviana, locally manufactured adzes are all Tridacna shell, reflecting a lack of quality stone. Oral traditions hint that specific rock types were importedRoviana people are held to have traded shell rings for 'greenstone' from Gizo and 'blackstone' from Rendova (Dureau 1994:56). Again, this suggests that quality stone was rare in Roviana, and access to axes was dependent on relations with other groups. The axes described above as being stylistically close to those from Bougainville are further evidence that axes were being imported (Miller 1979:53).

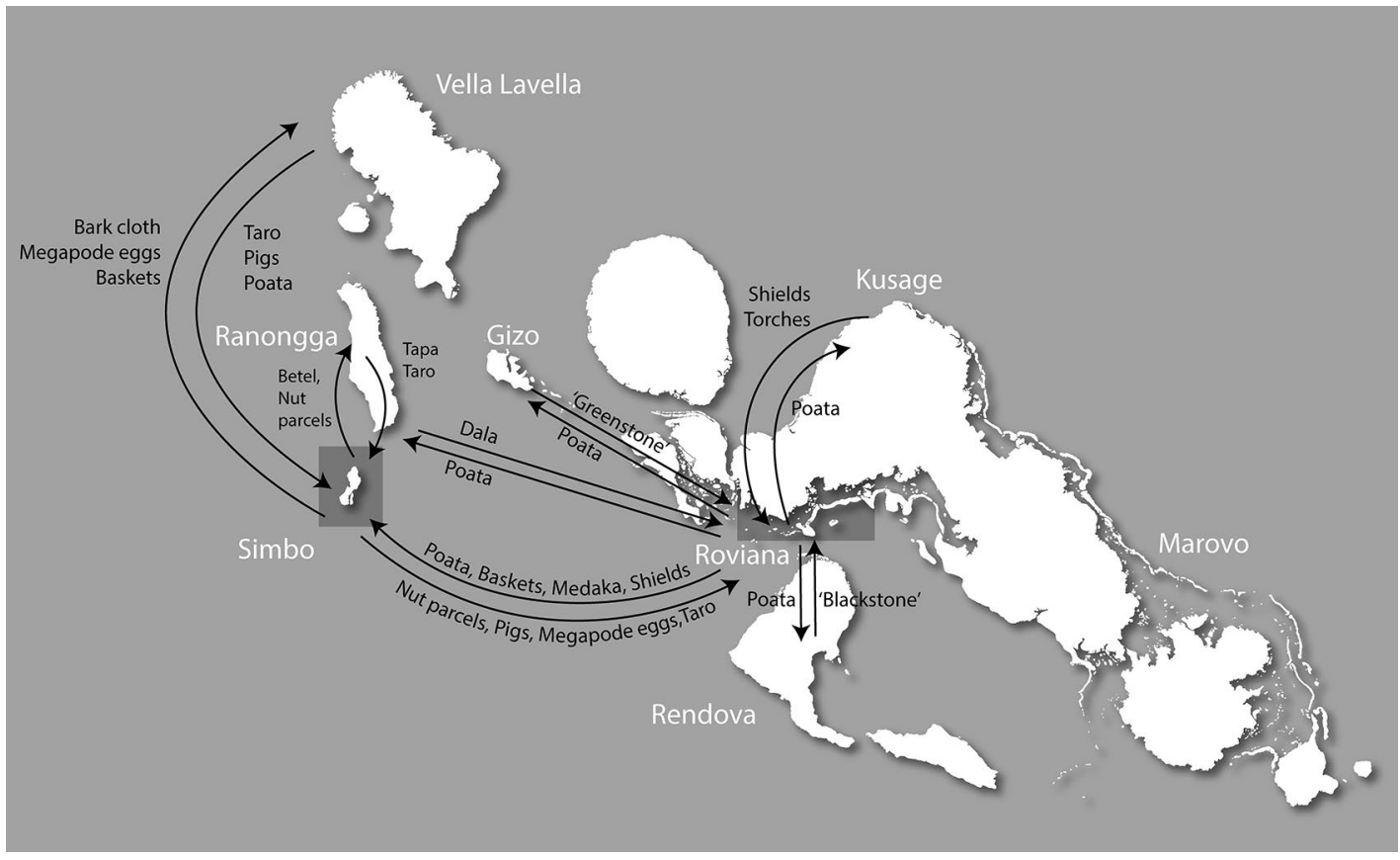

Figure 7.2. Some Simbo and Roviana trade partnerships recorded in western New Georgia.

Further connections occurred with Marovo, and as far afield as the Shortland Islands, Santa Isabel, Choiseul and the Central Solomons.

Source: Based on Hurford 2017:Map 3.4. 
Inter-group trade relations in New Georgia were focused on oppositional pairings of regionally produced items (Figure 7.2). For example, the Kusage region of north New Georgia was the renowned producer of wicker war shields (lave) and these were traded to Roviana in exchange for shell valuables. Simbo people acquired their shields from Roviana in exchange for packages of nuts, amongst other items (Hocart 1931:301). Such trade relationships were called baere and were established by the mutual exchange of shell rings between chiefs, which served to foster a categorisation of people from each party as being 'like brothers'-something that came with a whole series of moral imperatives (Thomas 2004:284-290). Baere partnerships served to encompass the internal relations of a tribe and its products in opposition to a paired equivalent party, and reframed trade between these entities as familial sharing (see McDougall 2004:204-212). Trade was therefore the exact opposite of headhunting — where the latter denied relations outside the tribe, the former modelled relations with other tribes as a larger-scale version of internal (sibling) relations.

The suggestion that axes had always been an item acquired through trade relations in Roviana and Simbo is important because it reminds us that the replacement of stone varieties with iron had social as well as material implications. When whalers and traders first brought iron axes to New Georgia they predominantly interacted with people on Simbo (McKinnon 1975). Although relatively isolated, with poor natural resources, Simbo had a deep harbour and a group of people with a reputation for being relatively friendly. As noted, many weapons were traditionally imported to Simbo from neighbouring islands: spears and bows came from the Shortland Islands, and shields came from Kusage via Roviana (Hocart 1931:301). Europeans slotted neatly into this pattern, representing a reasonably predictable opportunity to link into axe trading networks. And, according to the accounts of Andrew Cheyne in 1844 (Shineberg 1971), this is exactly what Simbo people did: they began taking iron axes to Roviana in exchange for hawksbill turtle shell. This was then traded back to Europeans for more axes-European traders were giving one axe head in return for as little as 1.5-3 pounds of 'tortoiseshell' (Shineberg 1971:305). Quite quickly both Roviana and Simbo had a plentiful supply of iron axes, and stone was abandoned.

This alignment of iron axe trade networks was part of a lasting alliance between Simbo and Roviana. It must also have severed relations with trade partners who had previously supplied stone axes: particularly those from further afield in Choiseul or Isabel. People from Roviana were still going to these latter places — not to acquire axes, but to acquire heads with their axes. And, on the way was Vaghena in Manning Straits, an important hawksbill nesting ground.

The people of Roviana used to go to Manning Straits to fish or catch turtle; sometimes they went headhunting besides ... Since the advent of traders they eat the flesh and sell the shell; they bring a few home alive. The way it began was that they once [took] some shell to Eddystone and the people there told them to keep it for the Europeans. (Hocart n.d.(b):1)

There was clearly some symmetry to this network of relations. The European production of axes was balanced against their demand for tortoiseshell, and the Roviana production of tortoiseshell was balanced against their demand for axes. The objects were caused by each other: Cheyne, for example, hired a Chinese blacksmith and shipped bars of iron for the sole purpose of making axes for New Georgia - although later traders relied on Sheffield edge tool manufacturers like Harrison $\&$ Sons. The fact that headhunting and hawksbill harvesting journeys were combined reinforces this symmetry, and highlights the entanglement of axes in the crux between creating and cutting relations.

Long-distance headhunting raids to Choiseul and Isabel increased between the 1870s and 1890s (Bennett 1987; Jackson 1978). Perhaps not coincidentally, this was also the time when European traders became resident: they married Roviana women and acquired land for permanent trade stores. I think it likely that this gradually turned iron axes (and other trade goods) into a 'local' 
item-they were acquired from people who had become relatives, or, at the very least, were resident baere. The part of axes that established bonds between people (their acquisition through friendly trade) was internalised, and at the same time, the violent relationship-severing quality of axes was amplified, in that it could now be applied to a greater number of outsiders. In terms of indigenous relations, the result was the production of a New Georgian enclave, whose partnerships extended towards Australia and Europe.

Changes in alliances at this time are reflected in oral traditions. Prior to the rule of a chief named Pequ (perhaps in the 1860s), the people of Roviana are said to have mostly raided Isabel. However, during Pequ's reign, the people of Choiseul became a target because a war party from there had killed his sister. Hocart's informants declared that Ingava, the successor to Pequ, only ever fought in Choiseul, while other chiefs simply added that island to Isabel as a valid locale for raids. At the same time that distant groups were becoming legitimate targets, local enemies became friends: 'In the olden days they also used to catch heads in Vella Lavella' (Hocart n.d.(c):1) but this was stopped after a peace exchange:

The mbangara of Roviana all went over to Vella Lavella and gave 6 to 10 shell rings to each mbangara. The mbangara of Vella Lavella came to Roviana with shell rings. After that Roviana, Eddystone, Vella Lavella, etc. did not fight with one another any longer but only against Ysabel and Choiseul. Mbitia gave rings to mbangara of Eddystone, Ganongga and Lunggu, but there was no fighting with them. Penggu [Pequ] would not fight them because they were like 'two brothers'. (Hocart n.d.(c):2)

It would be an exaggeration to claim that this shift in alliances and partnerships was solely a result of European residence. But it is clear that the confluence of events was such that alliances beyond the New Georgia region were no longer necessary. Choiseul could be attacked with regularity because there was no common sociality with them left to share; all partnerships were dissolved.

\section{Conclusion}

Trade axes had their origins in complex arrangements of relations involving social and material dimensions, and we could certainly follow these much further than I have done here: through trade supply routes to Europe, and the Sheffield iron industries, or other aspects of the colonial world system for example (Orser 2009). But however entangled axes were, the effect of their use in New Georgia was to cut this network, to create distinctions by individuating actors. The votu manja ceremony elicited efficacious axes out of a chain of relations - they were a composite thing, 'brought out' or 'made to appear'. Used successfully, they elicited a warrior who encompassed the agency of the axe and spirits. A chief claimed the efficacy of his ancestors and warriors through headhunting, and managed the relational boundaries of the tribe. Enemies were demarcated, but so were allied groups defined through oppositional trade- the composite one of a pair, 'like brothers'.

People in New Georgia clearly recognised agency as relational, and the individuations described did not completely elide their origins, as can be seen by the flows of shell rings and food offerings back through successive levels of encompassment in ceremonial contexts. Indeed, it was exactly because relational entanglement was considered to be a kind of primordial background state that acts of network cutting and encompassment were so necessary-it was the only way people and things could be seen to have properties and effects of their own.

In this sense, differentiation was a prevailing concern in New Georgian social practicewhilst artefacts like axes existed as manifestations of power gathered from chains of relations, they were used in the service of setting limits to those who could claim that power as their own. Chiefdoms in the region consequently did not seek to expand or integrate, but rather 
to differentiate-surrounding landscapes were depopulated rather than colonised. Even when regional alliances operated, these maintained distinction via reciprocal exchanges that established equivalent pairings.

Entanglement always needs its opposite then. Axes provide an edge where two perspectives meet-they are composed from relations, but they produce objects. We can certainly emphasise one of these perspectives over the other, but in fact social life always involves movement between relational entanglement and objectification, and the circumstantial character of this gives action and historical change its particular structure. As such, even small-scale ethnographic observables permeate larger-scale and longer-term structures amenable to archaeological analysis.

\section{References}

Allen, J. 1984. 'Pots and poor princes: A multidimensional approach to the study of pottery trading in Coastal Papua'. In The many dimensions of pottery: Ceramics in archaeology and anthropology, edited by $S$ van der Leew and A Pritchard, 407-463. Amsterdam: Institute of Prae- and Protohistory.

Aswani, S. 2000. 'Changing identities: The ethnohistory of Roviana predatory head-hunting'. Journal of the Polynesian Society 109 (1):39-70.

Bennett, JA. 1987. Wealth of the Solomons: A history of a Pacific archipelago, 1800-1978. Honolulu: University of Hawai i Press.

Coulson, F. 1985. 'Solomon Islands'. In The ocean basins and margins, Vol 7A, edited by A Nairn, F Stehli and S Uyeda, 607-682. New York: Plenum Press. doi.org/10.1007/978-1-4613-2351-8_13.

Dureau, C. 1994. 'Mixed blessings: Christianity and history in women's lives on Simbo, western Solomon Islands'. PhD thesis, Macquarie University, Sydney.

Dureau, C. 2000. 'Skulls, mana and causality'. Journal of the Polynesian Society 109 (1):71-97.

Feenberg, A. 1991. Critical theory of technology. New York: Oxford University Press.

Felgate, M. 2003. 'Reading Lapita in Near Oceania: Intertidal and shallow water pottery scatters, Roviana Lagoon, New Georgia, Solomon Islands'. PhD thesis, University of Auckland, Auckland.

Flexner, JL. 2016. 'Ethnology collections as supplements and records: What museums contribute to historical archaeology of the New Hebrides (Vanuatu)'. World Archaeology 48 (2):196-209. doi.org/ 10.1080/00438243.2016.1195769.

Gosden, C. 2004. Archaeology and colonialism: Cultural contact from 5000 BC to the present. Cambridge: Cambridge University Press.

Gregory, C. 1982. Gifts and commodities. London: Academic Press.

Hocart, AM. 1922. 'The cult of the dead in Eddystone of the Solomons'. Journal of the Royal Anthropological Institute of Great Britain and Ireland 52:71-117, 259-305. doi.org/10.2307/2843738.

Hocart, AM. 1931. 'Warfare in Eddystone of the Solomon Islands'. Journal of the Royal Anthropological Institute of Great Britain and Ireland 61:301-324. doi.org/10.2307/2843922.

Hocart, AM. n.d.(a). 'Chieftainship'. Unpublished manuscript. In Hocart papers, Alexander Turnbull Library, Wellington. MS-Papers-0060.

Hocart, AM. n.d.(b). 'Manning sts. \& turtle fishing' (Handwritten notes, Roviana). Unpublished manuscript. In Hocart papers, Alexander Turnbull Library, Wellington. MS-Papers-0060. 
Hocart, AM. n.d.(c). 'Warfare' (Handwritten notes, Roviana). Unpublished manuscript. In Hocart papers, Alexander Turnbull Library, Wellington. MS-Papers-0060.

Hodder, I. 2012. Entangled: An archaeology of the relationships between humans and things. Malden: Wiley-Blackwell. doi.org/10.1002/9781118241912.

Hodder, I. 2014. 'The entanglements of humans and things: A long-term view'. New Literary History 45 (1):19-36. doi.org/10.1353/nlh.2014.0005.

Hurford, J. 2017. 'Houses, shrines and the social landscape: A study of architecture on Tetepare, Solomon Islands'. MA thesis, University of Otago, Dunedin.

Hviding, E. 1996. Guardians of Marovo Lagoon: Practice, place and politics in maritime Melanesia. Pacific Islands Monograph Series 14. Honolulu: University of Hawai i Press.

Jackson, KB. 1978. 'Tie hokara, tie vaka: Black man, white man. A study of the New Georgia group to $1925^{\prime}$. PhD thesis, The Australia National University, Canberra.

Kirch, PV. 1988. 'Long-distance exchange and island colonization: The Lapita case'. Norwegian Archaeological Review 21:103-117. doi.org/10.1080/00293652.1988.9965475.

Latour, B. 1993. We have never been modern. Cambridge, Massachusetts: Harvard University Press.

Latour, B. 2013. An inquiry into modes of existence: An anthropology of the moderns. Translated by Catherine Porter. Cambridge, Massachusetts: Harvard University Press.

Law, J. 1992. 'Notes on the theory of the actor-network: Ordering, strategy, and heterogeneity'. Systems Practice 5 (4):379-393. doi.org/10.1007/BF01059830.

Leach, J and E Leach. 1983. The Kula: New perspectives on Massim exchange. Cambridge: Cambridge University Press.

Lukács, G. 1971. 'History and class consciousness: Studies in Marxist dialectics'. Cambridge, Massachusetts: MIT Press.

Malinowski, B. 1922. Argonauts of the western Pacific: An account of native enterprise and adventure in the archipelagos of Melanesian New Guinea. London: Routledge. doi.org/10.4324/9781315014463.

Marx, K. 1976. Capital: A critique of political economy. London: Penguin Books Limited.

Mauss, M. 1990. The gift: The form and reason for exchange in archaic societies. London: W.W Norton.

McDougall, D. 2000. 'Paths of pinauzu: Captivity and social reproductions in Ranongga'. Journal of the Polynesian Society 109 (1):99-113.

McDougall, D. 2004. 'The shifting ground of moral community: Christianity, property and place in Ranongga (Solomon Islands)'. PhD thesis, University of Chicago, Chicago.

McKinnon, JM. 1975. 'Tomahawks, turtles and traders: A reconstruction in the circular causation of warfare in the New Georgia Group'. Oceania 45 (4):290-307. doi.org/10.1002/j.1834-4461.1975. tb01872.x.

McNiven, IJ. 2013. 'Between the living and the dead: Relational ontologies and the ritual dimensions of dugong hunting across Torres Strait'. In Relational archaeologies: Humans, animals, things, edited by C Watts, 97-116. London: Routledge.

Miller, D. 1979. National sites survey summary report. Honiara: Solomon Islands National Museum.

Nagaoka, T. 2011. 'Late prehistoric-early history houses and settlement space on Nusa Roviana, New Georgia Group, Solomon Islands'. PhD thesis, University of Auckland, Auckland. 
Orser, CE. 2009. 'World-systems theory, networks, and modern-world archaeology'. In International handbook of historical archaeology, edited by D Gaimster and T Majewski, 253-268. New York: Springer. doi.org/10.1007/978-0-387-72071-5_14.

Reeve, R. 1989. 'Recent work on the prehistory of the western Solomons, Melanesia'. Bulletin of the Indo-Pacific Prehistory Association 9:46-67.

Scheffler, HW. 1965. Choiseul Island social structure. Berkeley: University of California Press.

Sheppard, PJ and R Walter. 2006. 'A revised model of Solomon Islands culture history'. Journal of the Polynesian Society 116:47-76.

Sheppard, PJ, R Walter and T Nagaoka. 2000. 'The archaeology of head-hunting in Roviana Lagoon, New Georgia, Solomon Islands'. Journal of the Polynesian Society 109 (1):4-38.

Shineberg, D. 1971. The trading voyages of Andrew Cheyne, 1841-44. Honolulu: University of Hawai' $\mathrm{i}$ Press.

Somerville, BT. 1897. 'Ethnographical notes in New Georgia, Solomon Islands'. Journal of the Royal Anthropological Institute of Great Britain and Ireland 26:357-413.

Specht, J. 1979. 'Axe heads and zoomorphs in the Solomon Islands'. In Birds of a feather: Osteological and archaeological papers from the South Pacific in honour of R.J. Scarlett, edited by A Anderson, 247-263. Oxford: British Archaeological Reports.

Strathern, M. 1988. The gender of the gift. Berkeley: University of California Press.

Strathern, M. 1990. 'Artifacts of history: Events and the interpretation of images'. In Culture and history in the Pacific, edited by J Siikala, 25-44. Helsinki: Finnish Anthropological Society.

Strathern, M. 1996. 'Cutting the network'. The Journal of the Royal Anthropological Institute 2 (3):517-535. doi.org/10.2307/3034901.

Summerhayes, G. 2000. Lapita interaction. Terra Australis 15. Canberra: Department of Archaeology and Natural History and Centre for Archaeological Research, The Australian National University.

Thomas, N. 1991. Entangled objects: Exchange, material culture and colonialism in the Pacific. Cambridge, Massachusetts: Harvard University Press.

Thomas, T. 2004. 'Things of Roviana: Material culture, personhood and agency in nineteenth century Solomon Islands'. PhD thesis, University of Otago, Dunedin.

Thomas, T. 2009. 'Communities of practice in the archaeology of New Georgia, Rendova and Tetepare'. In Lapita: Ancestors and descendants, edited by PJ Sheppard, T Thomas and G Summerhayes, 119-145. NZAA Monograph 28. Auckland: New Zealand Archaeological Association.

Thomas, T. 2013. 'Sensory efficacy in the material culture of New Georgia, Solomon Islands'. In Melanesia: Art and encounter, edited by L Bolton, N Thomas, E Bonshek, J Adams and B Burt, 199-208. London: British Museum Press.

Thomas, T. 2014. 'Shrines in the landscape of New Georgia'. In Monuments and people in the Pacific, edited by H Martinsson-Wallin and T Thomas, 47-76. Studies in Global Archaeology 20. Uppsala: Department of Archaeology and Ancient History, Uppsala University.

Thomas, T, P Sheppard, and R Walter. 2001. 'Landscape, violence and social bodies: Ritualized architecture in a Solomon Islands society'. The Journal of the Royal Anthropological Institute 7 (3):545-572. doi.org/ 10.1111/1467-9655.00077. 
Torrence, R and A Clarke. 2013. 'Creative colonialism: Locating indigenous strategies in ethnographic museum collections'. In Reassembling the collection: Ethnographic museums and indigenous agency, edited by R Harrison, S Byrne and A Clarke, 171-195. Santa Fe: School for Advanced Research Press.

Waite, D and K Conru. 2008. Solomon Islands art: The Conru collection. Milan: Five Continents Editions.

Walter, R and P Sheppard. 2000. 'Nusa Roviana: The archaeology of a Melanesian chiefdom'. Journal of Field Archaeology 27 (3):295-318. doi.org/10.1179/jfa.2000.27.3.295.

Walter, R, T Thomas and P Sheppard. 2004. 'Cult assemblages and ritual practice in Roviana Lagoon, Solomon Islands’. World Archaeology 36 (1):142-157. doi.org/10.1080/0043824042000192614.

Zelenietz, M. 1979. 'The end of head hunting in New Georgia'. In The pacification of Melanesia, edited by M Rodman and M Cooper, 91-108. Ann Arbor: University of Michigan Press. 
This text is taken from Archaeologies of Island Melanesia: Current approaches to landscapes, exchange and practice, edited by Mathieu Leclerc and James Flexner, published 2019 by ANU Press, The Australian National University, Canberra, Australia.

doi.org/10.22459/TA51.2019.07 